УДК 339.9(477.73)

DOI: https://doi.org/10.26642/jen-2019-4(90)-15-22

І.Т. Кіщак, д.е.н., проф.

К.О. Глубоченко, к.держ.упр., доц.

Миколаївський національний університет

імені В.О. Сухомлинського

І.П. Саваріна, к.е.н., доц.

Чорноморський національний університет імені Петра Могили

\title{
Стратегічні пріоритети розвитку підприсмств з виробництва складного обладнання
}

\begin{abstract}
Досліджено стратегічні пріоритети розвитку підприємств у сфері складного машинобудування на прикладі ДП НВКГ «Зоря»-«Машпроект». Визначення моделі стратегічного управління підприємства та ролі підприємства на національному рівні, дослідження техніко-технологічних та організаційно-управлінських заходів підприємства виокремлено як фактори, що сприятимуть нарощуванню обсягів виробництва експортоорієнтованої продукиї. На підставі ретроспективного, стратегічного аналізів та аналізу світового ринку серійних газотурбінних двигунів, установок та турбогенераторів обтрунтовано визначення моделі стратегічного управління державним підприємством, його ролі на національному рівні, проаналізовано техніко-технологічні та організаційно-управлінські заходи підприємства. Доведена конкурентоспроможність продукиї підприємства на світовому ринку складної машинобудівної техніки. Обгрунтована недостатня доиільність приватизачіі підприсмства в поточний період як стратегічно-важливого фактора національної безпеки. Розглянуто техніко-технологічні заходи, що застосовуються підприємством для нарощування обсягів виробниџтва та експорту турбін різного функиіонального призначення. Наявність контрольного пакета акцій державної форми власності на користування та оперативне управління підприємством; збереження та нарощування обсягів профільної діяльності підприємства з просуванням іміджу підприємства як суб'єкта господарювання України; здійснення профільно-орієнтованої діяльності підприємства під контролем органу державноі влади в частині звітності та їх спільної відповідальності в частині недопущення економічних та інших зловживань визначено як підвалини приватизації стратегічного ринкового підприємства $з$ урахуванням балансу інтересів держави та кон'юнктури ринку. Акцентовано увагу на необхідності державної фінансової підтримки економічного сектору з виробництва складного обладнання, у тому числі зазначеного підприємства. Запропоновано складові стратегічних засад розвитку галузі складного машинобудування.
\end{abstract}

Ключові слова: стратегія; складне машинобудування; управління стратегічним підприємством; національна безпека; стратегічне підприємство; експортоорієнтоване підприємство.

Актуальність теми. В умовах ринкових відносин і загострення конкурентної боротьби на ринках товарів і послуг існує необхідність розширення кола питань наукових досліджень у сфері економічної безпеки держави. При цьому особливого значення набувають методи оцінки та інструменти підвищення рівня економічної безпеки у сфері складного машинобудування.

У країнах з ринковою економікою ця галузь відіграє важливу роль як фактор інтенсифікації соціально-економічного розвитку. Для України проблема гарантування економічної безпеки держави як фактора розвитку складної машинобудівної промисловості має особливо важливе значення, що обумовлено, насамперед, сучасним станом розвитку вітчизняного сектору цієї галузі та нарощуванням виробничих потужностей, яке здійснюється переважно екстенсивним шляхом.

Об’єктивна необхідність державного регулювання складної машинобудівної галузі в умовах ринку викликана особливостями, притаманними цій галузі, іiі місцем і роллю у гарантуванні економічної безпеки держави. Як показує вітчизняний та зарубіжний досвід, негативні наслідки нестабільності внутрішнього та зовнішнього середовища істотно впливають на параметри іiі розвитку. Важливість теоретичного осмислення i методологічного забезпечення вдосконалення регуляторної політики розвитку складної машинобудівної галузі за глобальних змін зовнішнього середовища пояснюється, у першу чергу, потребою у швидкій адаптації даної галузі до нових обставин та у формуванні передумов для стабільного розвитку цього сектора економіки України у довгостроковій перспективі. Тому пошук нових теоретичних і практичних підходів до визначення стратегічних пріоритетів та політики у сфері складної машинобудівної галузі є актуальним завданням. 
Аналіз останніх досліджень та публікації, на які спираються автори. Зокрема, аспекти стратегічного розвитку державних підприємств світового значення як фактора національної безпеки розглядаються у роботах А.М. Баланович [7], К.П. Боримської [8], А.С. Гальчинського [9], О.І. Гудзь [10], I.T. Кіщака [12-14] та ін. Проблематика розглядається з точки зору пріоритету державної позиції або позицій державно-приватного партнерства як основи для стратегічного розвитку підприємств національного значення з виробництва складного обладнання. Аналіз іноземних публікацій із зазначеної проблематики дозволяє зробити висновок, що підприємства 3 виробництва складного обладнання (high tech industries) також є елементом стратегічного розвитку національної економіки, проте роль держави у цьому процесі не є первинною порівняно з діяльністю міжнародних корпорацій. Зокрема, A.ZakrzewskaBielawska [6] розглядає концептуальні основи стратегічного розвитку підприємств 3 виробництва складного обладнання з точки зору інтересів транснаціональних корпорацій. Martin C. та Leurent H. [3] прогнозують тенденції подальшого розвитку даної галузі у світі. Villamizar M.A. та інші [5] виокремлюють унікальні особливості даного високотехнологічного сектору та його світові перспективи. У контексті дослідження українського сектору високотехнологічного обладнання цікавим також $\epsilon$ звернення до досвіду інших країн в аналізі даного типу виробництва $[1 ; 2 ; 4]$. Зважаючи на результати грунтовних досліджень вітчизняних та зарубіжних науковців та практиків даної проблеми, можна зробити висновок, що сучасні реалії вимагають вивчення і розв'язання ряду науково-практичних завдань, пов'язаних із подальшим розвитком складної машинобудівної галузі, підвищенням економічної ефективності іiі діяльності 3 урахуванням інвестиційно-інноваційних складових, ролі держави, організаційно-управлінської перебудови та визначення на основі стратегічних імперативів принципів сталого функціонування галузі складного машинобудування.

Метою статті є визначення стратегічних пріоритетів розвитку підприємств з виробництва складної машинобудівної техніки (на прикладі ДП НВКГ «Зоря»-«Машпроект»).

Викладення основного матеріалу. 3 широкого кола проблемних питань, що стримують нарощування обсягів виробництва експортоорієнтованої продукції Державного підприємства Наукововиробничий комплекс газотурбобудування «Зоря»-«Машпроект», виокремлюємо такі:

- визначення моделі стратегічного управління підприємства;

- визначення ролі підприємства на національному рівні;

- дослідження техніко-технологічних та організаційно-управлінських заходів підприємства.

Зміст сутності поняття «стратегія» розуміємо як довготривалі, найбільш принципові і важливі настанови, плани, наміри (уряду, адміністрацій областей, керівництва підприємств) щодо виробництва та реалізації продукції (на внутрішньому i зовнішньому ринках), доходів i витрат, податків i капіталовкладень, цін та бюджету, соціального захисту. В свою чергу, стратегія управління конкурентоспроможністю підприємства - це програма дій, спрямованих на досягнення довготермінових конкурентних переваг підприємства, заснована на принципах гнучкості й адаптивності до змін зовнішнього середовища, інноваційності, системності та ситуаційності.

На думку О.Лозовського та М.Дячука, модель стратегічного управління, що орієнтована на створення та підтримку конкурентоспроможності підприємства, може мати такий вигляд (рис. 1).

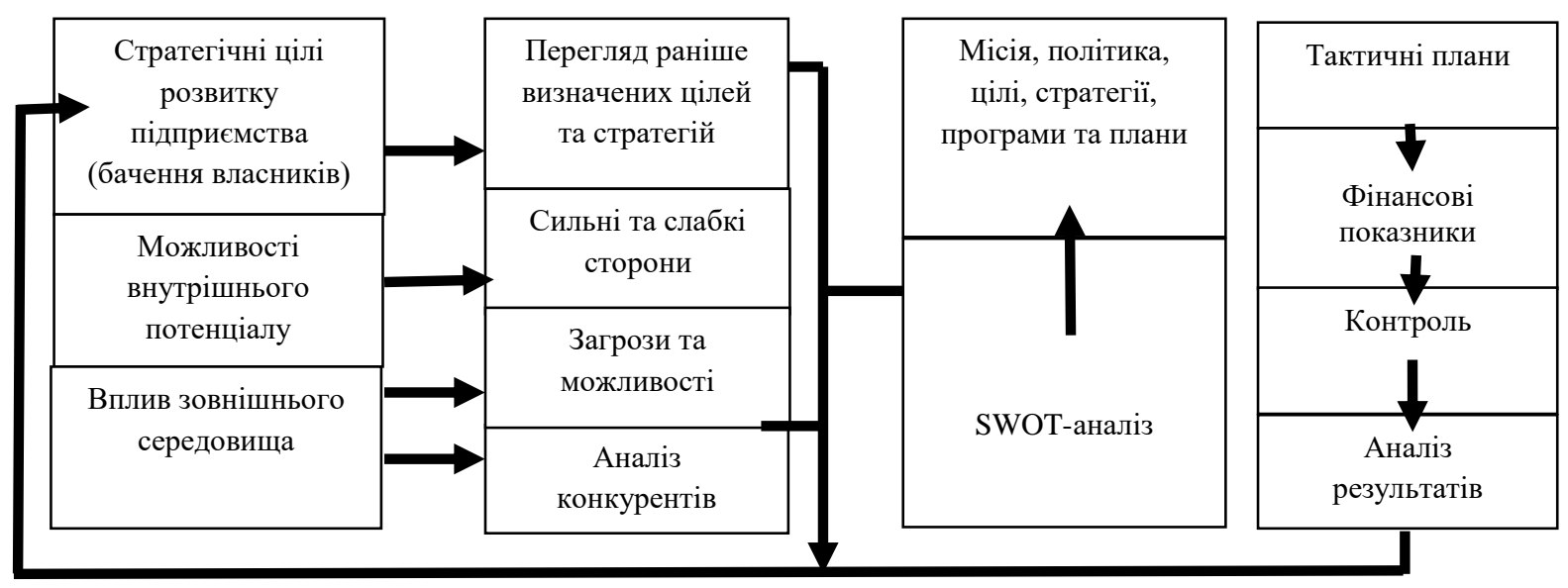

Рис. 1. Модель стратегічного управління підтримки конкурентоспроможності [6]

За твердженням авторів, основна мета стратегічного управління конкурентоспроможністю підприємства полягає в забезпеченні його ефективної діяльності та розвитку за умов нестабільності й мінливості факторів внутрішнього та зовнішнього середовищ. Підвищення конкурентоспроможності 
пов'язане $з$ розробкою та вибором відповідних стратегій, формування яких потребує постійного корегування та вдосконалення. Залежно від ринкової ситуації, умов середовища функціонування, рівня конкурентних переваг, методів конкурентного суперництва підприємство обирає відповідну стратегію конкурентоспроможності та модель поведінки [15, с. 31-35]. У цілому, погоджуючись із запропонованою моделлю стратегічного управління підтримки конкурентоспроможності підприємства (рис. 1), вважаємо за доцільне їі доповнення фактором участі держави в системі управління.

Стратегічне управління грунтується на аналізі взаємовідносин, які характеризують за допомогою системи «середовище-підприємство». Метою стратегічного аналізу результатів економіко-виробничої діяльності підприємства є змістовний опис об'єкта дослідження, виявлення особливостей тенденцій, можливих і неможливих напрямів його розвитку. В свою чергу стратегічне управління передбачає ретроспективний і стратегічний аналіз та аналіз ринків (потреб).

На світовому ринку серійних газотурбінних двигунів, редукторів, газотурбінних установок, турбогенераторів ДП НВКГ «Зоря»-«Машпроект» займає одне 3 провідних місць, оскільки його продукція $є$ конкурентоспроможною і користується попитом серед широкого кола споживачів. У свою чергу підприємства-конкуренти мають власну зацікавленість у сфері виробництва аналогічної технологічно складної техніки і реалізують цю діяльність відповідно до власних інтересів. Основними конкурентами підприємства у різних галузях є:

- на ринку продукції для газоперекачувальних станцій та морської продукції: Siemens AG (Німеччина), Rolls-Royce Motor Cars Ltd (Великобританія), General Electric Company (США), авіаремонтні підприємства Російської Федерації;

- на ринку продукції для енергетики: General Electric Company (США), SolarWorld Americas Inc. (США), Alstom (Франція), Siemens AG (Німеччина).

Світове визнання зазначених конкурентів ДП НВКГ «Зоря»-«Машпроект» свідчить про спроможність утримання ним конкурентних позицій 3 виробництва складної техніки. В таблиці 1 наведено обсяги збуту підприємством продукції на ринках країн світу.

Експорт продукиії підприємства до країн світу, \%

Таблиияя 1 (в обсягах до експорту)

\begin{tabular}{|c|c|c|c|}
\hline Ринки збуту продукції & $\mathbf{2 0 1 5}$ & $\mathbf{2 0 1 6}$ & $\mathbf{2 0 1 8}$ \\
\hline Індія & 39,6 & 79,5 & 30,1 \\
\hline Китай & 1,1 & 2,0 & 13,7 \\
\hline ОАЕ & 0,6 & 1,4 & 9,5 \\
\hline Узбекистан & - & - & 7,3 \\
\hline Білорусь & 1,4 & 5,6 & 1,1 \\
\hline В’єтнам & 22,9 & 6,0 & 2,1 \\
\hline Іран & 29,4 & 2,0 & - \\
\hline Росія & 4,3 & 2,4 & 22,4 \\
\hline Інші & 0,3 & 0,8 & \\
\hline Довідка: $[12 ; 16]$ & & & \\
\hline
\end{tabular}

Дані таблиці 1 свідчать, по-перше, про певну стабільність у 2015-2018 роках збуту продукції підприємства до країн-експортерів (за винятком Росії в 2018 році), появу нових (Узбекистан) та нереалізацію укладених контрактів із Казахстаном та Чехією [12, с. 73-79]. По-друге, перспективними країнами-партнерами для підприємства $є$ ті, що забезпечили нові ринки реалізації його продукції (Єгипет, Пакистан, країни Європейської спільноти, Перської Затоки та Південно-Східної Азії).

За всіма ознаками ДП «Зоря»-«Машпроект» належить до стратегічної групи підприємств, що посідають близькі позиції на ринку та конкурують між собою на основі тих самих конкурентних переваг і однакових методів. Це підтверджуються зокрема такими ознаками: близька структура асортименту продукції; задоволення попиту споживачів, які потребують однакових функціональних особливостей виробів; пропозиція на ринку аналогових послуг і технічної допомоги в експлуатації тощо.

Ретроспективний аналіз дозволяє дослідити основні техніко-економічні показники підприємства (обсяги реалізації, рентабельність, витрати, обсяги кредитних ресурсів тощо). У свою чергу цей аналіз $є$ базисом для подальшого аналізу виробничого потенціалу (цільове оцінювання) підприємства у внутрішньому та зовнішньому середовищі при здійсненні стратегічного аналізу по визначенню місця підприємства на зовнішньому ринку. У таблиці 2 наведено структуру обсягів реалізації основних видів продукції підприємством за поточний період (2019 рік - прогноз авторів). 
Структура обсягів реалізачії основних видів продукціі

\begin{tabular}{|c|c|c|c|}
\hline \multirow{2}{*}{ oo } & Показники & \multicolumn{2}{|c|}{ Період } \\
\cline { 2 - 3 } & Турбіни газові & $\mathbf{2 0 1 8}$ & $\mathbf{2 0 1 9}$ \\
\hline 1 & - одиниць & 3 & 23 \\
& - млн грн & 308,9 & 3146,0 \\
\hline 2 & - питома вага в обсягах реалізації, \% & 15,4 & 67,1 \\
& Ремонт двигунів та турбін & 20 \\
& - одиниць & 28 & 640,7 \\
& - млн грн & 967,7 & 13,7 \\
\hline 3 & Запасні частини & 48,2 & 762,5 \\
& - плн грн & 558,4 & 16,3 \\
\hline 4 & - питома вага в обсягах реалізації, \% & 27,8 & 137,1 \\
\hline
\end{tabular}

Довідка: узагальнено за $[16,17]$

Отже, чистий дохід від реалізації продукції (товарів, робіт, послуг) у 2018 році склав 2008,5 млн грн; за розрахунками в 2019 році має складати 4686,4 млн грн; в 2020 році - 4780,1 млн грн та в 2021 році 4875,7 млн грн [16]. Значне зростання виробництва кількості газових турбін з трьох у 2018 році до 23 одиниць у 2019 році обумовлено укладанням контрактів зі стратегічним партнером підприємства МВС Індії. До номенклатури поставок увійшли газотурбінні двигуни, редуктори, комплекти запасних частин. Обладнання призначене для кораблів різного складу МВС Індії: всього на них експлуатується більше 150 газотурбінних двигунів розробки і виробництва ДП «Зоря»-«Машпроект» [17]. За наявності замовлень на продукцію підприємства зазначені суми дохідної частини мають право на існування: в 2016 році загальний обсяг склав 4817,8 млн грн (за цінами на той період) [12, с. 73-79]. У 2016 році підприємством вироблено 32 турбінних двигуни та відремонтовано 11 двигунів. За своєю місією підприємство на $90 \%$ й більше є експортоорієнтованим на виробництво складного машинобудівного обладнання.

3 позиції стратегічного розвитку України у галузі складного машинобудування та визнання іiі світовою економіко-виробничою спільнотою підприємств вважаємо, що виключення ДП «Зоря»«Машпроект» 3 переліку об’єктів права державної власності, які не підлягають приватизації, є не зовсім доцільним. Натомість, у практичному плані підвищення рівня експортних потужностей підприємства має базуватися на стратегічних засадах прогнозування його розвитку 3 використанням економічного інструментарію SWOT-аналізу та на цих підставах надання йому державних інвестицій.

Про стратегічну недоцільність приватизації підприємства свідчать низка ринкових факторів. Поперше, підприємство є одним 3 лідерів світового газотурбобудування. Науковий та виробничий потенціал підприємства дозволяє проектувати та виготовляти турбіни для кораблів, електроенергетики, газотранспортних магістралей та надавати низку профільних послуг у суміжних галузях економіки. За державної підтримки підприємство здатне забезпечити внутрішній ринок своєю продукцією, що сприятиме стабілізації економічної безпеки держави та підвищенню її обороноздатності.

По-друге, враховуючи сучасний стан конкурентоспроможності продукції підприємства, що підтверджується наявністю контрактів на ï виготовлення та постачання до широкого кола країн світу, можна вважати, що його приватизація посилить конкурентні позиції підприємств-конкурентів 3 виробництва аналогічної продукції. Приватизація стратегічно значущого, єдиного й унікального на пострадянському просторі та бюджетоутворюючого для міста Миколаєва підприємства також може вплинути на ринкові позиції України на світовому ринку складного машинобудування, призвести до втрати цілісності комплексу українського газотурбобудування та обороноздатності держави, а також дестабілізувати соціально-економічний стан у регіоні за рахунок звільнення значної кількості працівників підприємства.

По-третє, погоджуючись із необхідністю формування дохідної частини державного бюджету, доцільно розглянути приватизацію державних підприємств, які внаслідок не досить вдалого менеджменту є збитковими, та стратегічно неважливих для забезпечення стабільного й ефективного функціонування виробничих та соціально-економічних систем країни. В цілому процес приватизації має проходити відкрито і публічно, з урахуванням економічних показників, соціальних потреб та інтересів 
колективів таких підприємств, та має бути орієнтованим на довго- та короткостроковий стратегічний розвиток регіону та країни в цілому.

По-четверте, враховуючи баланс інтересів держави та кон’юнктури ринку, у разі приватизації стратегічного ринкового підприємства, підвалинами підприємства мають бути: а) наявність контрольного пакета акцій державної форми власності на користування та оперативне управління підприємством; б) збереження та нарощування обсягів профільної діяльності підприємства 3 просуванням іміджу підприємства як суб'єкта господарювання України; в) здійснення профільноорієнтованої діяльності підприємства під контролем органу державної влади в частині звітності та їх спільної відповідальності в частині недопущення економічних та інших зловживань.

Результати більш детальнішого ретроспективного та стратегічного аналізів і досліджень ринку й поведінки підприємств лідерів-конкурентів з виробництва профільної продукції формують підстави для застосування SWOT-аналізу. Використання цього інструментарію в практичному плані дає можливість визначити сильні та слабкі сторони, можливості та загрози підприємства у внутрішньому та зовнішньому середовищах. Підходи щодо підвищення конкурентоспроможності продукції підприємства мають описувати послідовність і взаємозв'язок необхідних заходів, підкреслювати важливість стратегічного управління в забезпеченні довготермінових конкурентних переваг підприємства. За нашим розумінням стратегія розвитку підприємства має базуватися на таких складових (рис. 2).

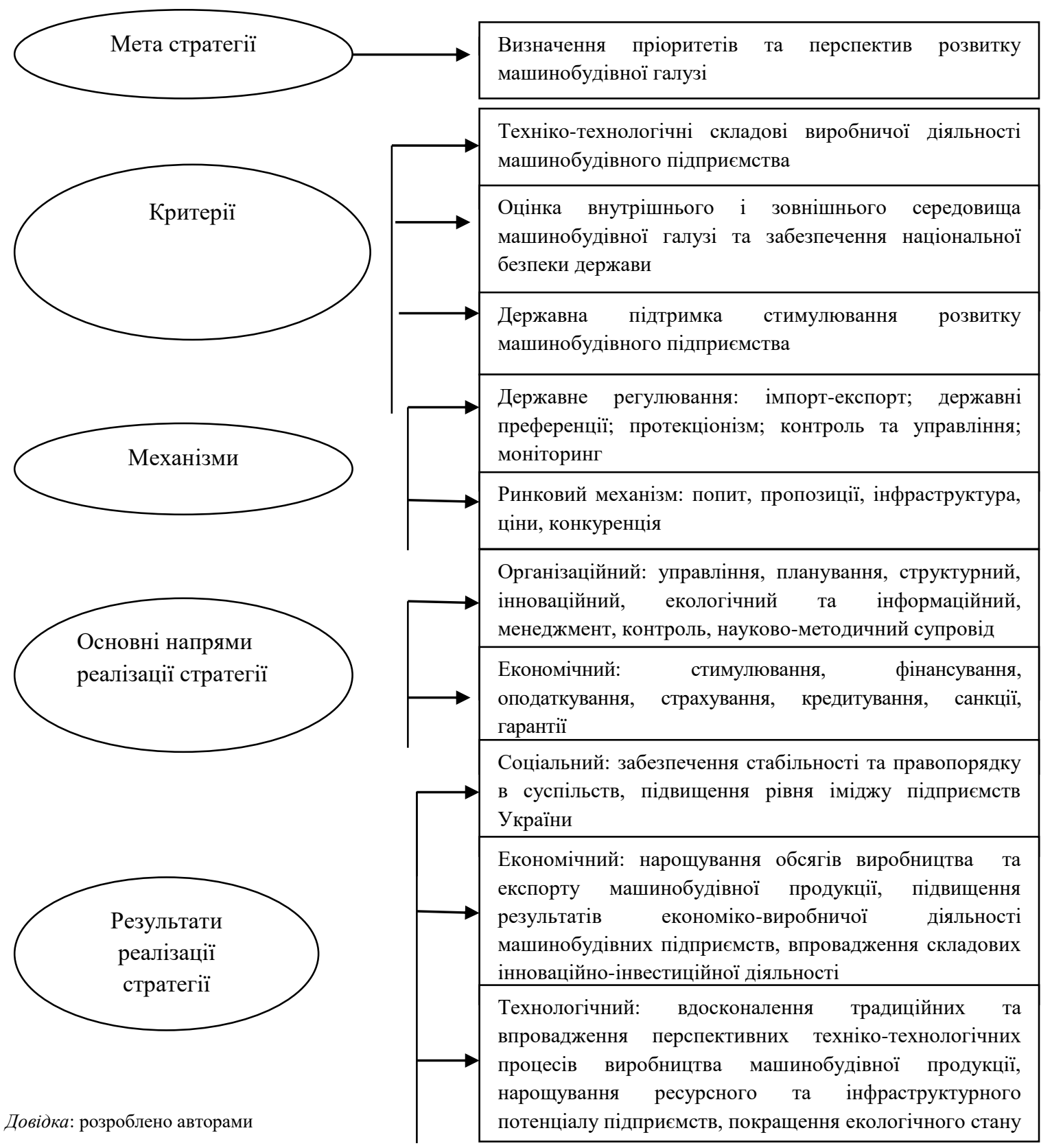

Рис. 2. Стратегічні засади розвитку складного машинобудування в Україні 
Отже, ДП «Зоря»-«Машпроект» розглядаємо як одне із стратегічно важливих підприємств держави як у частині забезпечення національної безпеки, так і обороноздатності країни. На підприємстві у 2018 році здійснено ряд проектів із реконструкції будівель та споруд, заміни застарілого та модернізації функціонуючого устаткування та обладнання, зокрема, реконструйовано виробничі цехи; впроваджено в експлуатацію нове високопродуктивне технологічне обладнання та новітнє обладнання для зберігання інформації. На найближчу перспективу підприємство планує впровадити низку заходів, а саме:

- створення нових промислових газотурбінних двигунів потужністю 32 та 60 МВт для розширення пропозиції підприємства на ринку газотурбінних установок;

- удосконалення газотурбінних установок, що серійно виготовляються для забезпечення відповідності їх екологічних характеристик сучасним вимогам;

- забезпечення контролю за експлуатацією технологічного, підйомно-транспортного енергетичного обладнання комплексу та за його безпечною роботою;

- проведення переговорів із банківськими установами щодо оптимізації тарифів на розрахунковокасове обслуговування, гарантійні і кредитні операції та відсотки по кредитах;

- переоформлення чинних договорів, укладання нових кредитних договорів, договорів про надання гарантійних і вексельних операцій за мінімально можливими ставками, що склалися на ринку таких послуг;

- удосконалення організаційної структури управління підприємства, централізація функцій управління, забезпечення оптимального завантаження робочих місць та інше.

Проте можемо виокремити й низку проблемних питань ДП НВКГ «Зоря»-«Машпроект», які потребують вирішення на державному рівні. Зокрема:

впровадження державної політики щодо надання фінансових преференцій підприємствам газо-, гідро-, електростанцій та Збройних Сил України з метою розміщення їх замовлень на продукцію ДП НВКГ «Зоря»-«Машпроект», що в свою чергу сприятиме розвитку його потужностей, національної безпеки та підвищенню обороноздатності України;

- створення сучасної конкурентоздатної техніки (газотурбінних двигунів потужністю 32, 60 MBT та іншої), що визначатиме експортний потенціал як Миколаївської області, так і держави в цілому, потребує значної суми коштів, яких у підприємства недостатньо;

- фінансування науково-дослідних і дослідно-конструкторських робіт потребує законодавчого надання можливості державному підприємству передбачити у фінансовому плані вивільнення коштів за рахунок зменшення суми прибутку, що оподатковується, на величину ресурсів, спрямованих на інноваційне оновлення основних фондів.

На жаль, поза увагою залишилися пропозиції науковців, висловлені у 2002 році щодо необхідності формування інноваційної моделі розвитку економіки України. Зокрема, А.Гальчинський та інші зазначали, що основою нового стратегічного курсу розвитку економіки має стати опрацювання та реалізація державної політики, спрямованої на створення необхідних економічних, інституційних, науково-технічних та соціальних передумов утвердження України як високотехнологічної держави, її входження до кола високотехнологічних країн світу. Отже, підтримка підприємства може стати фундаментом не лише економічної стратегії безпеки, а й політичної консолідації нації [9, с. 86]. Таким чином, функціонування даного підприємства є фактором національної безпеки держави. Боримська К. зазначає, що у визначенні економічної безпеки держави має бути враховано: 1) наявність цілеспрямованої політики державного регулювання економічними процесами в контексті реалізації проголошених стратегій соціально-економічного розвитку країни; 2) виявлення факторів, які забезпечують макроекономічну стабілізацію, збереження цілісності держави та іiі економічної незалежності, а також факторів, які стримують дані процеси [8, с. 29]. Отже, проблематика залишається актуальною, адже зазначені пропозиції науковців поки що не були враховані владними структурами та урядами країни з 2002 року до останнього часу (2019 рік).

Висновки та перспективи подальших досліджень. Застосування запропонованих критеріїв SWOTаналізу та наші комплексні системні дослідження у сфері складної машинобудівної галузі (дослідження організаційно-технологічних засад реалізації зовнішньоекономічної діяльності підприємства [12, с. 4244]; конкурентоспроможності продукції підприємства [13, с. 73-79]; конкурентоспроможності підприємства на зовнішніх ринках [14, с. 60-66];) результатів економіко-виробничої та експортної діяльності ДП «Зоря»-«Машпроект» 32010 року дозволяють сформувати такі висновки:

- складна машинобудівна галузь є досить специфічною: акумулюючи у своїй продукції здобутки суміжних сфер промисловості (машинобудування, суднобудування, металургія, електротехніка тощо), вона одночасно стимулює розвиток власне цих та інших галузей. 3 одного боку, це є індикатором рівня розвитку економіки держави в цілому, з другого - стимулюючою ланкою економічно специфічних галузей;

- 3 позиції стратегічного розвитку України у галузі складного машинобудування та визнання іiі світовою економіко-виробничою спільнотою виключення ДП «Зоря»-«Машпроект» 3 переліку об’єктів 
права державної власності, які не підлягають приватизації, є не зовсім доцільним. У практичному плані підвищення рівня експортних потужностей підприємства має базуватися на стратегічних засадах прогнозування його розвитку з використанням економічного інструментарію SWOT-аналізу та на цих підставах надання йому державних інвестицій;

- ДП «Зоря»-«Машпроект» розглядаємо як одне із стратегічно важливих підприємств держави як у частині забезпечення національної безпеки, так i обороноздатності країни. За всіма ознаками підприємство входить до стратегічної групи підприємств світу, що посідають близькі позиції на ринку та конкурують між собою на основі тих самих конкурентних переваг і за допомогою однакових методів;

- необхідним $\epsilon$ впровадження державної політики щодо надання фінансових преференцій підприємствам газо-, гідро-, електростанцій та Збройних Сил України з метою розміщення їх замовлень на продукцію ДП НВКГ «Зоря»-«Машпроект», що в свою чергу сприятиме національній безпеці та підвищенню обороноздатності України.

Результати дослідження формують теоретико-методологічні засади подальших наукових напрацювань у сфері визначення стратегічних засад розвитку різних галузей економіки на ринкових засадах в умовах жорсткої конкуренції на світовому ринку.

\section{Список використаної літератури:}

1. Keeble D.E. High-technology industry and regional development in Britain: The case of the Cambridge phenomenon / D.E. Keeble // Environment and Planning: Government and Policy. - 1989. - Vol. 7. - P. 153-172.

2. $\mathrm{KMPG} / /$ Remaining competitive in the technology industry: Implementing growth strategies in the new realities of the tech industry. - 2015 [Електронний ресурс]. - Режим доступу : https://home.kpmg/content/dam/kpmg/pdf/2015/10/remaining-competitive.pdf.

3. Martin C. Technology and innovation for the future of production: Accelerating value creation / C.Martin, H.Leurent. - Geneva : World Economic Forum, 2017.

4. Tsai J. International brand strategy of Taiwanese hi-tech enterprises / J.Tsai, H.-Y.Hung // Agricultural Economics (Czech Republic). - 2007. - Vol. 53 (2). - P. 83 -88.

5. Villamizar M.A. (2017). Characterization of the manufacturing sectors of high and medium-high technology compared with other industrial sectors / M.A. Villamizar, A.Cobo, R.Raha // Journal of Technology Management \& Innovation. - 2017. - Vol. 12 (1). - P. 39-48.

6. Zakrzewska-Bielawska A. High technology company - concept, nature, characteristics / A.Zakrzewska-Bielawska // Recent Advances in Management, Marketing, Finances. - 2010. - Vol. 1. - P. 93-98.

7. Баланович А.M. Обгрунтування стратегій розвитку промислового підприємства на основі ринкових тенденцій : дис.на здобуття наук. ступеня канд. екон. наук : 8.00 .04 / А.М. Баланович. - Х., 2018. - 343 с.

8. Боримська К.П. Економічна безпека держави й підприємства: визначення змісту понять / К.П. Боримська // Вісник ЖДТУ / Серія : Економічні науки. - 2012. - № 4 (62). - С. 25-30.

9. Інноваційна стратегія українських реформ / А.С. Гальчинський, В.М. Геєць, А.К. Кінах, В.П. Семиноженко.К. : Знання України, 2002. - 336 с.

10. Гудзь O.I. Стратегія розвитку підприємства: сутність та класифікація / O.I. Гудзь // Економіка і суспільство. - 2018. - Вип. 18. - С. 346-352.

11. Данилов И. Готовся к большой распродаже / И.Данилов // Вечерний Николаев. -8 октября. -2019.

12. Кіщак I.T. Конкурентоспроможність продукції ДП НВКГ «Зоря»-«Машпроект» / I.T. Кімак, I.B. Копитіна // Матеріали міжнародної науково-практичної конференції «Економіка і менеджмент - 2015: перспективи інтеграції та інноваційного розвитку», Дніпропетровськ, 23-24 квітня 2015 р. - Дніпропетровськ : Біла К.О., 2015. - T. 5. - C. 42-44.

13. Кіщак I. Конкурентоспроможність підприємства на зовнішніх ринках / I.T. Кіщак, А.В. Слюсаренко. О.Л. Божок // Науковий вісник Миколаївського національного університету ім. В.О. Сухомлинського «Економічні науки: збірник наукових праць». - 2017. - № 1 (8). - С. 73-79.

14. Кіщак I.T. Організаційно-технологічні засади здійснення зовнішньоекономічної діяльності ДП НВКГ «Зоря»-«Машпроект» / I.T. Кімак, В.В. Лагодієнко, Р.С. Зубков // Науковий вісник Миколаївського національного університету ім. В.О. Сухомлинського «Економічні науки: збірник наукових праць». 2013. - Вип. 1. - С. 60-66.

15. Лозовський $O$. Стратегічне управління як чинник підвищення конкурентоспроможності підприємства / О.Лозовський, М.Дячук // Науковий вісник Миколаївського національного університету ім. В.О. Сухомлинського «Економічні науки: збірник наукових праць». - 2018. - № 2 (11). - С. 31-35.

16. Офіційний сайт ДП НВКГ «Зоря»-«Машпроект» [Електронний ресурс]. - Режим доступу : http://www.zorya.com.ua.

17. Турбинисты займутся индзаказом // Вечерний Николаев. - 1 октября. - 2019. - С. 1.

\section{References:}

1. Keeble, D.E. (1989), «High-technology industry and regional development in Britain: The case of the Cambridge phenomenon», Environment and Planning: Government and Policy, Vol. 7, pp. 153-172. 
2. KMPG (2015), Remaining competitive in the technology industry: Implementing growth strategies in the new realities of the tech industry, [Online], available at: https://home.kpmg/content/dam//kpmg/pdf/2015/10/remainingcompetitive.pdf

3. Martin, C. and Leurent, H. (2017), Technology and innovation for the future of production: Accelerating value creation, World Economic Forum, Geneva.

4. Tsai, J. and Hung, H.-Y. (2007), «International brand strategy of Taiwanese hi-tech enterprises», Agricultural Economics (Czech Republic), Vol. 53 (2), pp. 83-88.

5. Villamizar, M.A., Cobo, A. and Raha, R. (2017), «Characterization of the manufacturing sectors of high and medium-high technology compared with other industrial sectors», Journal of Technology Management \& Innovation, Vol. 12 (1), pp. 39-48.

6. Zakrzewska-Bielawska, A. (2010), «High technology company - concept, nature, characteristics», Recent Advances in Management, Marketing, Finances, Vol. 1, pp. 93-98.

7. Balanovych, A.M. (2018), Obgruntuvannja strategij rozvytku promyslovogo pidpryjemstva na osnovi rynkovyh tendencij, Ph.D. Thesis, Kharkiv, 343 p.

8. Boryms'ka, K.P. (2012), «Ekonomichna bezpeka derzhavy j pidpryjemstva: vyznachennja zmistu ponjat'», Visnyk ZDTU, Serija Ekonomichni Nauky, Vol. 4 (62), pp. 25-30.

9. Gal'chynskyj, A.S., Gejec, V.M., Kinah, V.P. and Semynozhenko, V.P. (2002), Innovacijna Strategija Ukrajins'kyh Reform, Znannja Ukrajiny Publ., Kyiv, 336p.

10. Gudz', O.I. (2018), «Strategija rozvytku pidpryjemstva: sutnist' ta klasyfikacija», Ekonomika i Suspilstvo, Vol.18, pp. $346-352$

11. Danylov, I. (2019), Gotovsja k bol'shoj rasprodazhe, Vechernij Nikolaev.

12. Kischak, I.T. and Kopytina, I.V. (2015), «Konkurentospromozhnist' produkciji DP NVKG Zorja-Mashproekt», Materialy mizhnarodnoji naukovo-praktychnoji konferentsiji Ekonomika I menedjment - 2015: perspektyvy integraciji ta innovatsijnogo rozvytku, Dnipropetrovsk, pp. 42-44.

13. Kischak, I.T., Slusarenko, A.V. and Bozhok, O.L. (2017), «Konkurentospromozhnist' pidpryjemstva na zovnishnih rynkah», Naunovyj Visnyk Mykolaivskogo nacionalnogo universytetu im. V.O. Suhomlynskogo "Ekonomichni Nauky: Zbirnyk Naukovyh Prac'», vol. 1 (8), pp. 73-79.

14. Kischak, I.T., Lagodijenko, V.V., Zubkov, R.S. (2013), «Organizacijno-tehnologichni zasady zovnishn'oekonomichnoji dijal'nosti DP NVKG Zorja-Mashproekt», Naunovyj Visnyk Mykolaivskogo nacionalnogo universytetu im. V.O. Suhomlynskogo «Ekonomichni Nauky: Zbirnyk Naukovyh Prac'», Vol. 1, pp. 60-66.

15. Lozovs'kyj, O. and Djachuk, M. (2018), «Strategichne upravlinnja jak chynnyk pidvyschennja konkurentospromozhnosti pidpryjemstva», Naunovyj Visnyk Mykolaivskogo nacionalnogo universytetu im. V.O. Suhomlynskogo «Ekonomichni Nauky: Zbirnyk Naukovyh Prac'», Vol. 2 (11), pp. 31-35.

16. Oficijnyj sajt DP NVKG Zorja-Mashproekt, [Online], available at: http://www.zorya.com.ua

17. «Turbinisty zajmutsja indzakazom» (2019), Vechernij Nikolaev, p. 1.

Кіщак Іван Теодорович - доктор економічних наук, професор Миколаївського національного університету імені В.О. Сухомлинського.

Наукові інтереси:

- дослідження складових мікро- та макроекономічних процесів ефективного функціонування підприємств та регіонів держави.

Глубоченко Катерина Олександрівна - кандидат наук 3 державного управління, доцент Миколаївського національного університету імені В.О. Сухомлинського.

Наукові інтереси:

- вплив органів державного управління на регіональну економіку та підприємницьку діяльність;

- удосконалення механізмів митного регулювання;

- впровадження технологій електронного урядування на регіональному рівні.

Саваріна Ірина Петрівна - кандидат економічних наук, доцент Чорноморського національного університету імені Петра Могили.

Наукові інтереси:

- ефективність управління суб'єктів господарювання;

- резерви покращення економічних результатів діяльності підприємств;

- удосконалення структури управління сучасного підприємства;

- підвищення рівня розвитку підприємницьких формувань. 